\title{
MIR4457 wt Allele
}

National Cancer Institute

\section{Source}

National Cancer Institute. MIR4457 wt Allele. NCI Thesaurus. Code C118122.

Human MIR4457 wild-type allele is located within chromosome 5 and is approximately 70 bases in length. This allele, which encodes MIR4457 pre-miRNA, may be involved in transcriptional regulation. 